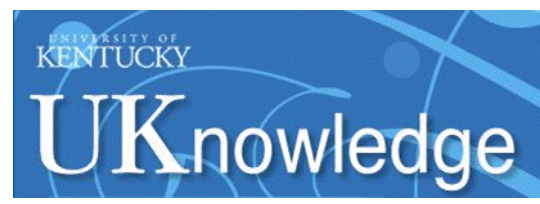

University of Kentucky

UKnowledge

$11-1990$

\title{
Implications of Thermal Events on Thrust Emplacement Sequence in the Appalachian Fold and Thrust Belt: Some New Vitrinite Reflectance Data
}

\author{
Sharon E. Lewis \\ Montana Tech \\ James C. Hower \\ University of Kentucky, james.hower@uky.edu
}

Follow this and additional works at: https://uknowledge.uky.edu/caer_facpub

Part of the Geology Commons

Right click to open a feedback form in a new tab to let us know how this document benefits you.

\section{Repository Citation}

Lewis, Sharon E. and Hower, James C., "Implications of Thermal Events on Thrust Emplacement Sequence in the Appalachian Fold and Thrust Belt: Some New Vitrinite Reflectance Data" (1990). Center for Applied Energy Research Faculty and Staff Publications. 11.

https://uknowledge.uky.edu/caer_facpub/11

This Article is brought to you for free and open access by the Center for Applied Energy Research at UKnowledge. It has been accepted for inclusion in Center for Applied Energy Research Faculty and Staff Publications by an authorized administrator of UKnowledge. For more information, please contact UKnowledge@lsv.uky.edu. 
Implications of Thermal Events on Thrust Emplacement Sequence in the Appalachian Fold and Thrust Belt: Some New Vitrinite Reflectance Data

\author{
Digital Object Identifier (DOI) \\ https://doi.org/10.1086/629462 \\ Notes/Citation Information \\ Published in The Journal of Geology, v. 98, no. 6, p. 927-942. \\ (C) 1990 by The University of Chicago. All rights reserved.
}

The copyright holder has granted the permission for posting the article here. 


\title{
IMPLICATIONS OF THERMAL EVENTS ON THRUST EMPLACEMENT SEQUENCE IN THE APPALACHIAN FOLD AND THRUST BELT: SOME NEW VITRINITE REFLECTANCE DATA ${ }^{1}$
}

\author{
SHARON E. LEWIS AND JAMES C. HOWER ${ }^{2}$ \\ Montana Bureau of Mines and Geology, Montana Tech, Butte, Montana 59701
}

\begin{abstract}
Interpretation of existing geothermometry data combined with new vitrinite reflectance data, within the framework of a detailed composite tectonic setting, elucidates the evolution of structural sequencing of thrust sheets during the Alleghanian event in the Valley and Ridge Province in Virginia. That the Pulaski thrust sheet preceded the Saltville thrust sheet in the emplacement sequence, and that both reached thermal maxima prior to, or during, respective emplacement may be inferred from vitrinite and other geothermometry data. In contrast, the Narrows and St. Clair thrust sheets probably each attained their thermal maximum after emplacement. New vitrinite reflectance data are consistent with CAI and other temperature-sensitive information heretofore ascertained in the Valley and Ridge Province and support previously established maximum temperatures of ca. $200^{\circ} \mathrm{C}$ for strata of the Saltville thrust sheet as young as Mississippian. $\mathbf{R}_{\max }$ values from Mississippian coals in the Price Formation of the Saltville sheet, beneath but near the Pulaski thrust, range from $1.61 \%$ to $2.60 \%$. At the structural front of the fold and thrust belt, a single Mississippian coal sample from the Bluefield Formation yields an $\mathbf{R}_{\max }$ value of $1.35 \%$. Those coals showing highest $R_{\max }$ values are more intensely fractured with secondary minerals filling the fractures. Warm fluids introduced during tectonic events may have played at least as important a role as that of combined stratigraphic and tectonic burial.
\end{abstract}

\section{INTRODUCTION}

Although fold and thrust belts typically are generated during a singular orogenic event, internally they are a composite of discrete structural sequences. Within crystalline portions of orogens, timing of metamorphism and plutonism is crucial for determining thrust sequences and docking order of terranes, (e.g., Rast 1989; Dallmeyer et al. 1986). For fold and thrust belts, deciphering the thermal history of sedimentary strata provides similar, equally important data constraining timing and the emplacement sequence of thrust systems.

The Appalachian Valley and Ridge Province is an example wherein geothermometry and related data, combined with an evolving understanding of the structural relationships of component thrust sheets, provide keys to Appalachian thrust belt evolution. Data from vitrinite reflectance (this study; Ingram and Rimstidt 1984), conodont alteration index

\footnotetext{
${ }^{1}$ Manuscript received September 8, 1989; accepted July 31, 1990.

${ }^{2}$ University of Kentucky, Kentucky Center for Applied Energy Research, 3572 Iron Works Pike, Lexington, Kentucky 40511.

[Journal of GeOLOGy, 1990, vol. 98, p. 927-942] (C) 1990 by The University of Chicago. All rights reserved.

0022-1376/90/9806-0011\$1.00
}

(CAI) (Epstein et al. 1977), "illite crystallinity" and clay mineralogy (Zentmeyer 1985), and the level of organic maturation (Stanley and Schultz 1983) contribute independent indicators of conditions of subgreenschist facies "metamorphism" in a portion of the Virginia Valley and Ridge Province of the Southern Appalachians (figs. 1 and 2). This "metamorphism" constrains the time of emplacement of individual thrust sheets and thus relates to the overall thrust emplacement sequence as well.

\section{TECTONICS AND DISTRIBUTION OF STRATIGRAPHIC SEQUENCES}

Four major thrust systems (figs. 2 and 3), named for their lower bounding thrusts, juxtapose Paleozoic strata between the metamorphic rocks of the Blue Ridge Province (fig. 2) on the southeast and the Appalachian Plateau on the northwest, where the structural front of the fold and thrust belt is marked by the axis of the Glen Lyn syncline (McDowell 1982) beneath the St. Clair thrust. The structural style and internal complexity of the Pulaski system, as depicted by Bartholomew (1987) and Schultz (1988), occupies an intermediate relationship between the structurally superjacent Blue Ridge thrust system and the more typical decollement thrust systems of the Valley and Ridge farther west. Thrust sheets structurally below the Pulaski 


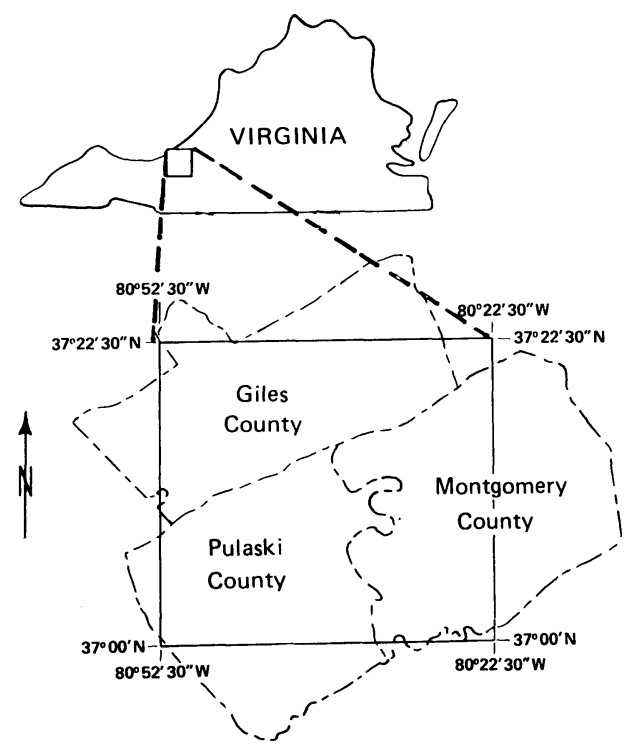

Fig. 1.-Map showing location of sample area relative to state and county boundaries.

sheet neither possess the internal complexity exhibited by the Pulaski sheet (Lewis and Bartholomew 1989), nor have as much horizontal displacement as the Pulaski thrust sheet (Bartholomew 1987).

Each major Valley and Ridge thrust sheet in southwestern Virginia has an endemic stratigraphy (fig. 4). Composite stratigraphic sections compiled by Bartholomew (1987) for each thrust sheet permit reconstruction of stratigraphy intrinsic to that thrust sheet (fig. 4). Reconstruction of the particular stratigraphic columns from which our samples, and other data pertinent to this discussion, were collected, is essential for evaluating possible effects of stratigraphic burial.

Mississippian coals crop out adjacent to the present day leading edge of, and in windows through the Pulaski sheet. Between the outcrop belts, drill hole data (Bartholomew and Lowry 1979; Stanley and Schultz 1983) provide limited information on coals within the Saltville sheet below the Pulaski thrust (figs. 2 and 3). These coals occur within the lower $40 \mathrm{~m}$ of the upper Price Formation (Mississippian) (fig. 4), just above the marine to nonmarine transition; environments of deposition of the Price Formation are discussed by Kreisa and Bambach (1973) and Whitehead (1979). The lower and upper of the two principal recognized coal units are the "Langhorne," and the "Merrimac," respectively. Environments of deposition of these Price Formation coals are addressed by Brown (1983) and Zentmeyer (1985). Approximately $0.5 \mathrm{~km}$ of Mississippian rocks remain preserved stratigraphically above the coalbearing strata (fig. 4), but structurally beneath the Pulaski thrust in the Price Mountain window (fig. 3). Tournaisian (Early Mississippian) rocks are the youngest overridden strata exposed on the Saltville thrust sheet. Middle Ordovician limestones (CAI obtained by Epstein et al. 1977) on the Saltville thrust sheet are stratigraphically overlain by approximately $3 \mathrm{~km}$ of strata, including coalbearing Mississippian strata similar to that of the Price Mountain window (fig. 4).

Mississippian coal also crops out along the southeastern flank of the structural front where, in the Glen Lyn syncline (fig. 4) north of Bluefield, West Virginia, preserved Pennsylvanian and Mississippian stratigraphic overburden was at least $1.5 \mathrm{~km}$ (Cooper 1961). Where limestones of the Mississippian Greenbrier Formation (Visean) are exposed close to the structural front, they lie stratigraphically beneath (fig. 4) approximately 1 $\mathrm{km}$ of strata that includes the Bluefield Formation $(0.2 \mathrm{~km})$, which contains the coal, plus part of the overlying Hinton Formation $(0.8 \mathrm{~km})$. No strata older than Devonian are exposed in this part of the Glen Lyn syncline, but the pre-Devonian stratigraphic section is probably similar to that above the structurally superjacent St. Clair thrust (fig. 4). On the St.Clair thrust sheet, approximately 2.5

FIG. 2.-Generalized geologic map (modified after Bartholomew 1987 and Schultz et al. 1986) showing distribution of Mississippian-age strata and major thrust faults. Numbers in parentheses are $\mathbf{R}_{\max }$ values for surface sample locations and range of $R_{\max }$ values for drill hole locations from table 1 . YSF $=$ Yellow Sulphur fault; 7.5 minute quadrangle abbreviations: NAR = Narrows, NEW = Newport, BLA = Blacksburg, RN = Radford North, STA = Staffordsville, WF = White Gate, PUL = Pulaski. SE-NW line is the line of cross section in figure 3. Dark line within the shaded Mississippian outcrop belt on the Saltville thrust sheet follows the Price Formation coals. G-Greenbrier Formation in the Glen Lyn syncline. CO-Cambro-Ordovician strata; SD-Siluro-Devonian strata. 


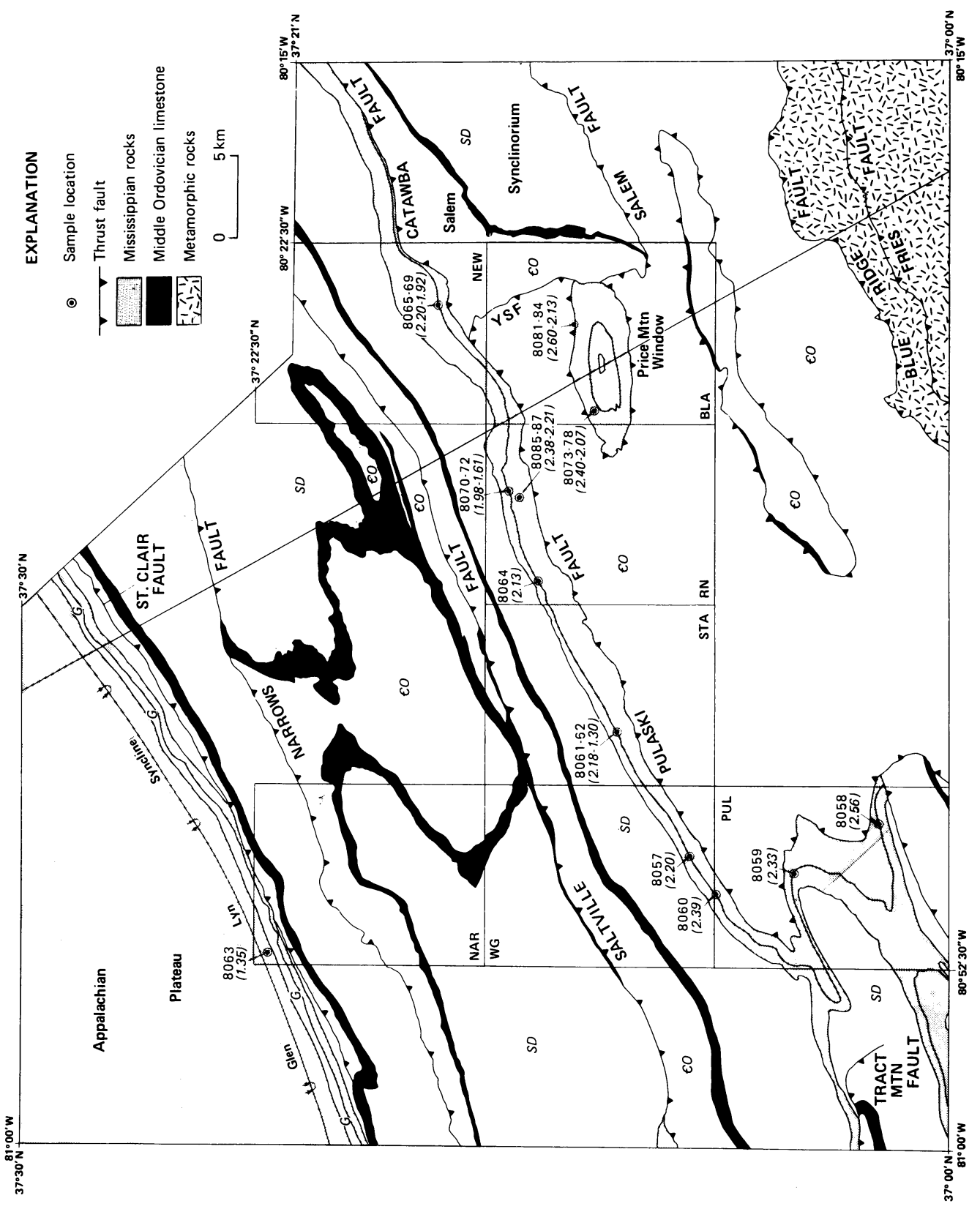



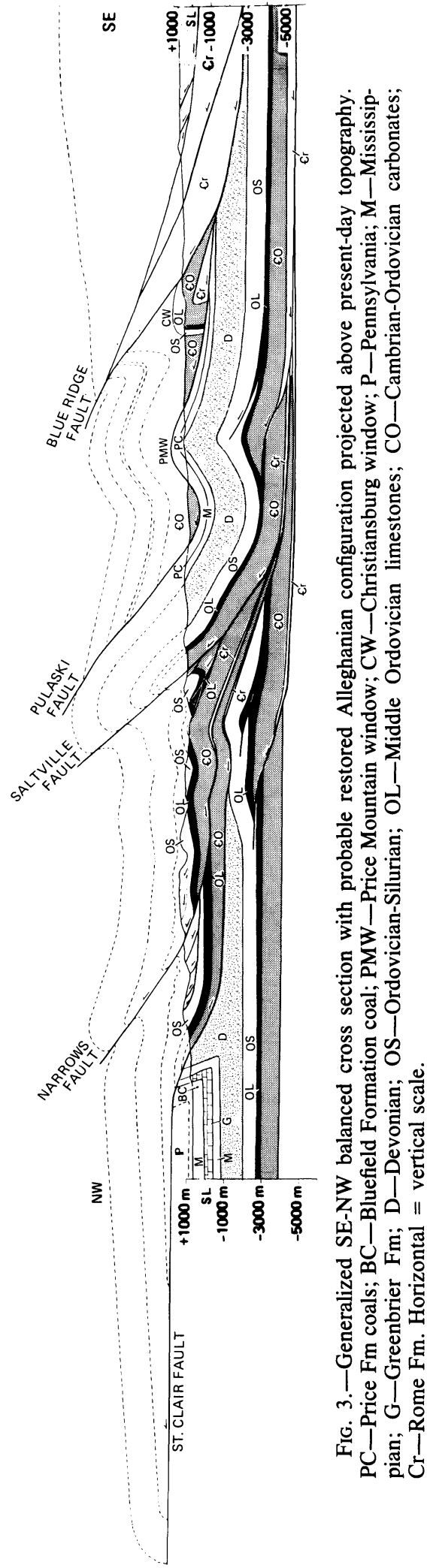

$\mathrm{km}$ of Ordovician to Devonian strata stratigraphically overlie middle Ordovician limestones from which CAI was obtained by Epstein et al. (1977).

\section{VALLEY AND RIDGE THERMAL HISTORY}

Previous Work.-Campbell and others (1925) delineated the various Valley Fields on the basis of coal rank as defined by the "fuel ratio" (fixed carbon/volatile matter). By their definition, the Price Mountain (Montgomery County) and Pulaski (Pulaski County) fields fall into the semi-anthracite rank range. Coals from the Brush and Little Walker Mountain areas (both sampled by us) are described by them as including both semi-anthracite and low-volatile bituminous rank coals. Fields, not sampled for this study but described by Campbell and others (1925), southwest of the Price-Brush-Little Walker Mountains area include semi-anthracites from the Max Meadows field (Wythe County) and low-volatile bituminous coals from Reed Creek (Wythe County), Lick Creek, and Bland (Bland County) fields. Their samples from the Lick Creek and Bland County fields are the only ones in the Narrows thrust sheet (below the Saltville fault). The data of Campbell and Others (1925) suggest that this field has the lowest rank coals from any of the Valley Fields. Farther west, out of the Valley Fields, Hower and Rimmer (1990) report that lowvolatile bituminous coals from the Pocahontas basin in southern West Virginia-Virginia decrease in rank 15-20 km eastward from central Buchanan County, Virginia, toward the structural front and the St. Clair fault.

Stanley and Schultz (1983) provided chemical analyses for the major coal beds in W6534 (Sunnyside test; our samples 8085-8087) and W-6535 (Merrimac test; our samples

FIG. 4.-Stratigraphic columns showing relative stratigraphy on Pulaski (western Salem synclorium), Saltville, Narrows, and St. Clair thrust sheets and in Glen Lyn synclinorium (modified after Bartholomew 1987). P-Mc-Pennsylvanian-Mississippian clastic sequence; Mbf-Bluefield Fm; Mg-Greenbrier Fm; Mmc-Maccrady Fm; Mpr (u;l;c)-Price Fm (upper, lower, and Cloyd members); Dc-Chemung Fm; Ss-Silurian sandstones; Oc-Ordovician clastic sequence; Ols-Middle Ordovician limestones; O-Ccb-Ordovician-Cambrian carbonates; $\mathrm{Cr}$-Rome Fm. 


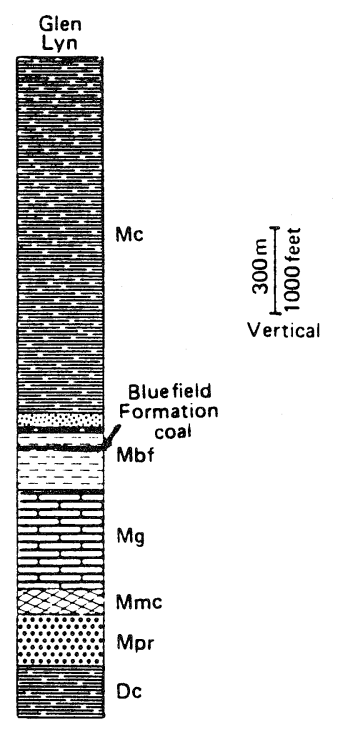

$\frac{8 \mathrm{~km}}{5 \text { miles }}$

Horizontal
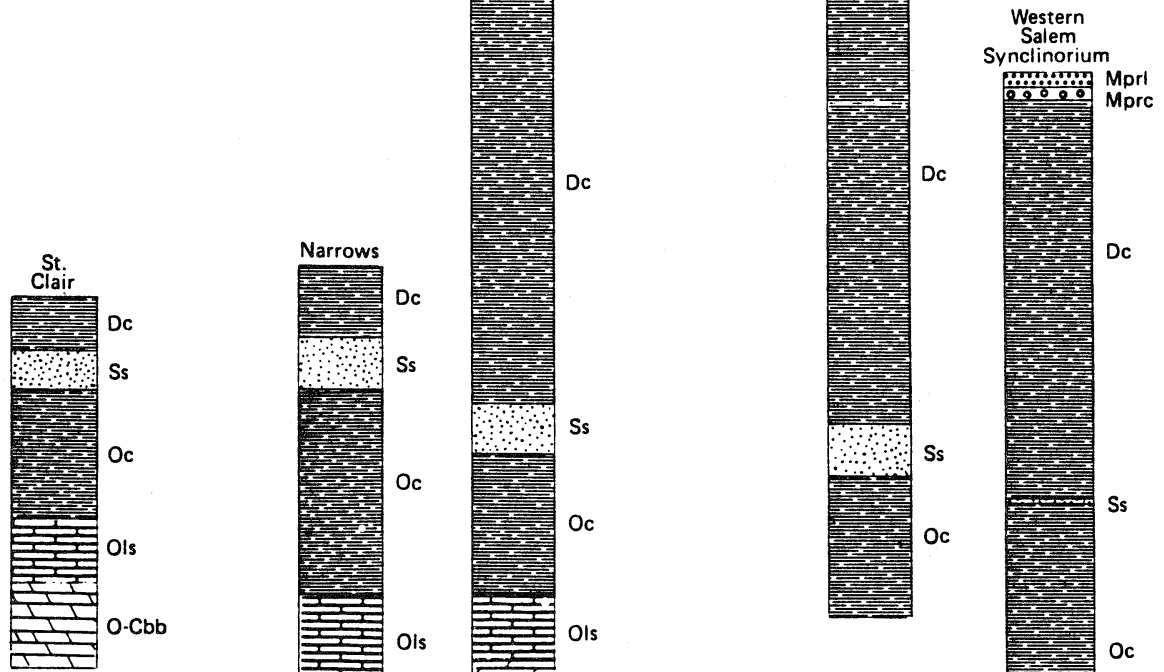

Dc

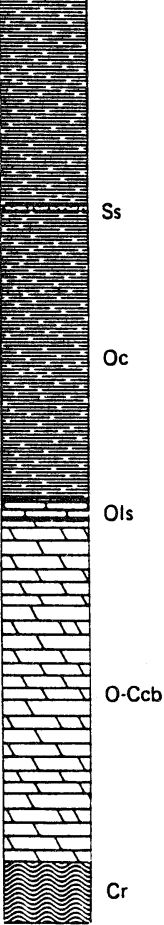


8081-8084) cores. Volatile matter (daf) ranges from 12.6-19.2\% for the Sunnyside coals and 12.3-16.7\% for the Merrimac coals. If "coals" with greater than $20 \%$ ash (dry) are excluded, the range for coals from both cores is reduced to $12.6-14.9 \%$ volatile matter.

Sample Locations. - Vitrinite reflectance and anisotropy values (table 1) were determined for 29 samples from 11 separate locations in Montgomery and Pulaski counties in Virginia and for one sample from northwestern Giles County, Virginia (figs. 1 and 2). Price Formation coals were sampled from both the outcrop belt and drill core holes just northwest of the trace of the Pulaski thrust and from the Price Mountain window. All samples, except one, are from the upper (nonmarine) member of the Early Mississippian (Tournaisian) Price Formation. The exception (8063) is from the Middle Mississippian (Visean) nonmarine Bluefield Formation on the overturned southeastern limb of the Glen Lyn syncline near the Virginia-West Virginia border in Giles County, Virginia (fig. 2).

Coal Characteristics and Rank.-Vitrinite maximum-reflectance and anisotropy $\left(R_{\max }-\right.$ $\mathbf{R}_{\text {mean }} / \mathbf{R}_{\text {max }}$ ) values of Mississippian-age coal samples for this study are given in table 1 . These coals generally are within the range for semi-anthracite rank (see Davis 1978, for delineation of rank by reflectance) but exhibit variations both vertically and geographically. The top coal from Coal Bank Hollow \#1 (8065) and the three coals from Lick Run \#5 (8071-8073) are within the low volatile bituminous range; two of the lower coals from Coal Bank Hollow \# $1(8066 ; 8068)$ are transitional from low volatile bituminous to semianthracite in rank. The upper coal from the State Highway 100 (8061) outcrop shows a medium volatile bituminous reflectance value $\left(1.30 \% \mathrm{R}_{\mathrm{max}}\right)$, which is likely the consequence of surface weathering of that coal (Ingram and Rimstidt 1984) and not an indication of actual rank. The sample (8063, table 1) from the Bluefield Formation also has a medium volatile bituminous reflectance $\left(1.35 \% \mathrm{R}_{\max }\right)$. Surficial processes may have reduced the true rank here as well, because the sample was obtained within only $30 \mathrm{~cm}$ of the surface of the exposure.
The presence of probable epigenetic minerals was determined by optical examination of the coals (comments column of table 2), supplemented by reconnaissance X-ray diffraction analysis of low-temperature ashes (K. A. Frankie and F. L. Fiene 1983 pers. comm.). Aside from quartz and kaolinite, potential epigenetic minerals include sulfides: pyrite, marcasite, and sphalerite (fig. 5); and carbonates: calcite, magnesite, dolomite, ankerite, and siderite. Carbonates occur as both veins and cements between brecciated coal fragments (fig. 6). Chlorite (composition unknown) occurs from trace amounts up to $20 \%$ in several ashes. Illite "crystallinity" (M. R. Bayan 1989 pers. comm.), determined for a variety of lithologies from the "Merrimac" seam (from a core that included our samples KCER 8081-8084), generally falls near the diagenesis/anchizone transition, as would be expected based on the vitrinite maximum reflectances of the associated coals in that core (2.13-2.60\% $\left.\mathrm{R}_{\max }\right)$. Illite composition, particularly the presence of $\mathrm{NH}_{4}^{+}=$illite common in higher rank coals, can complicate the interpretations of "crystallinity" (Juster et al. 1987; Daniels and Altaner 1990; Daniels et al. 1990).

Geothermometry: Depth Indicators.Conodont alteration index values (CAI) (Epstein et al. 1977; Harris 1979) provide the most extensive geothermometry data available for the entire Valley and Ridge Province. CAI values are highest on the southeasternmost thrust sheets and decrease successively northwestward (fig. 6). Middle Ordovician rocks on the Pulaski sheet yield CAI values up to 5 and generally are between 4 and 5 . Regionally, on the Saltville thrust sheet, CAI values range from 3 to 4 in Middle Ordovician limestones, whereas, in Middle Ordovician limestones in the St. Clair thrust sheet, CAI values range from 2 to 3 (Epstein et al. 1977; Harris 1979). In Mississippian limestones near the structural front beneath the St.Clair thrust, CAI values (Epstein et al. 1977; Harris 1979) are 2-2.5 except locally near Glen Lyn, Virginia where they reach 3 or higher. Within part of our sampling area, Zentmeyer (1985) used CAI values of Epstein et al. (1977) plus her study of clay mineralogy (dickite/kaolinite) and "illite crystallinity" to suggest a temperature range of $150^{\circ} \mathrm{C}$ to 


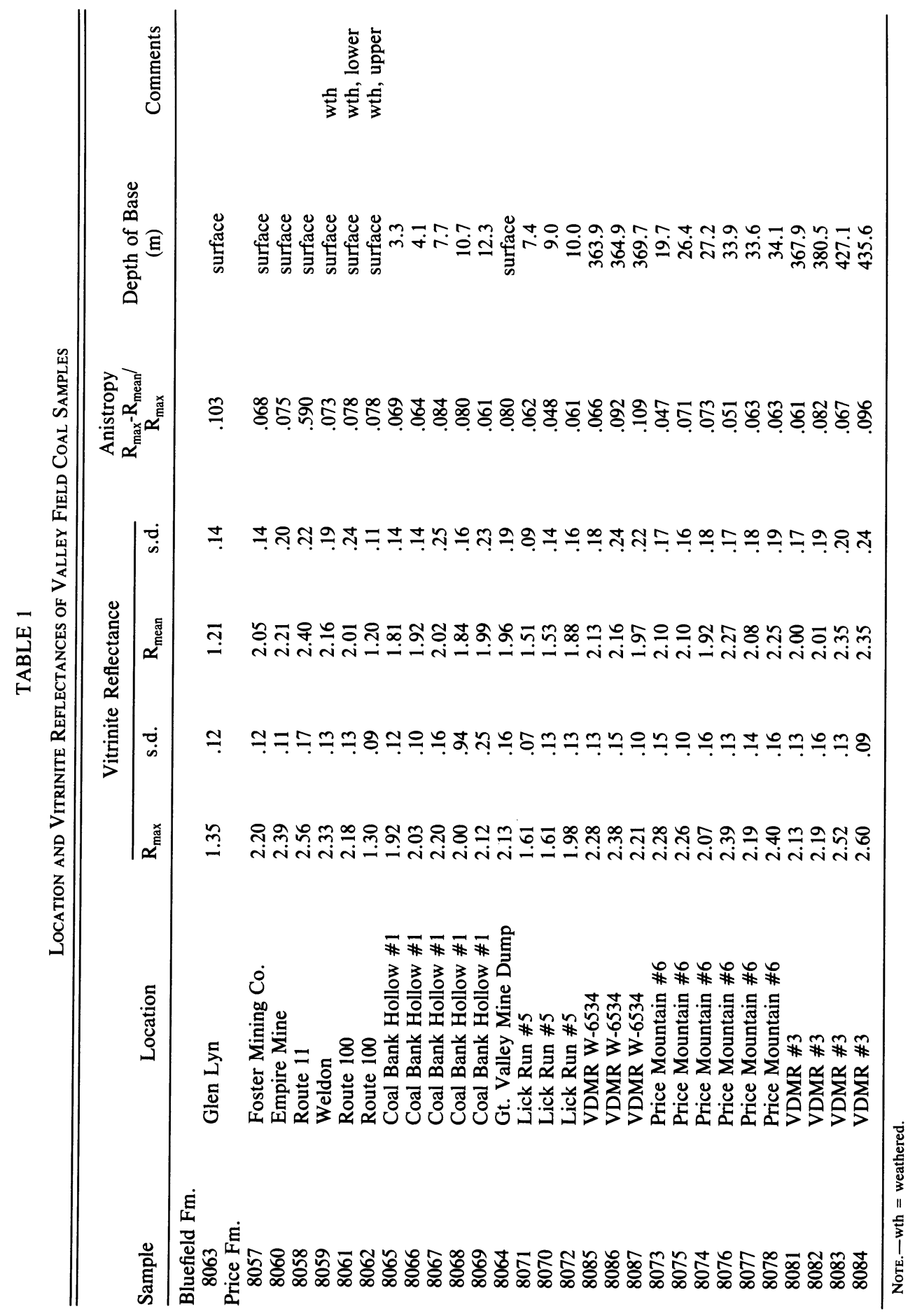




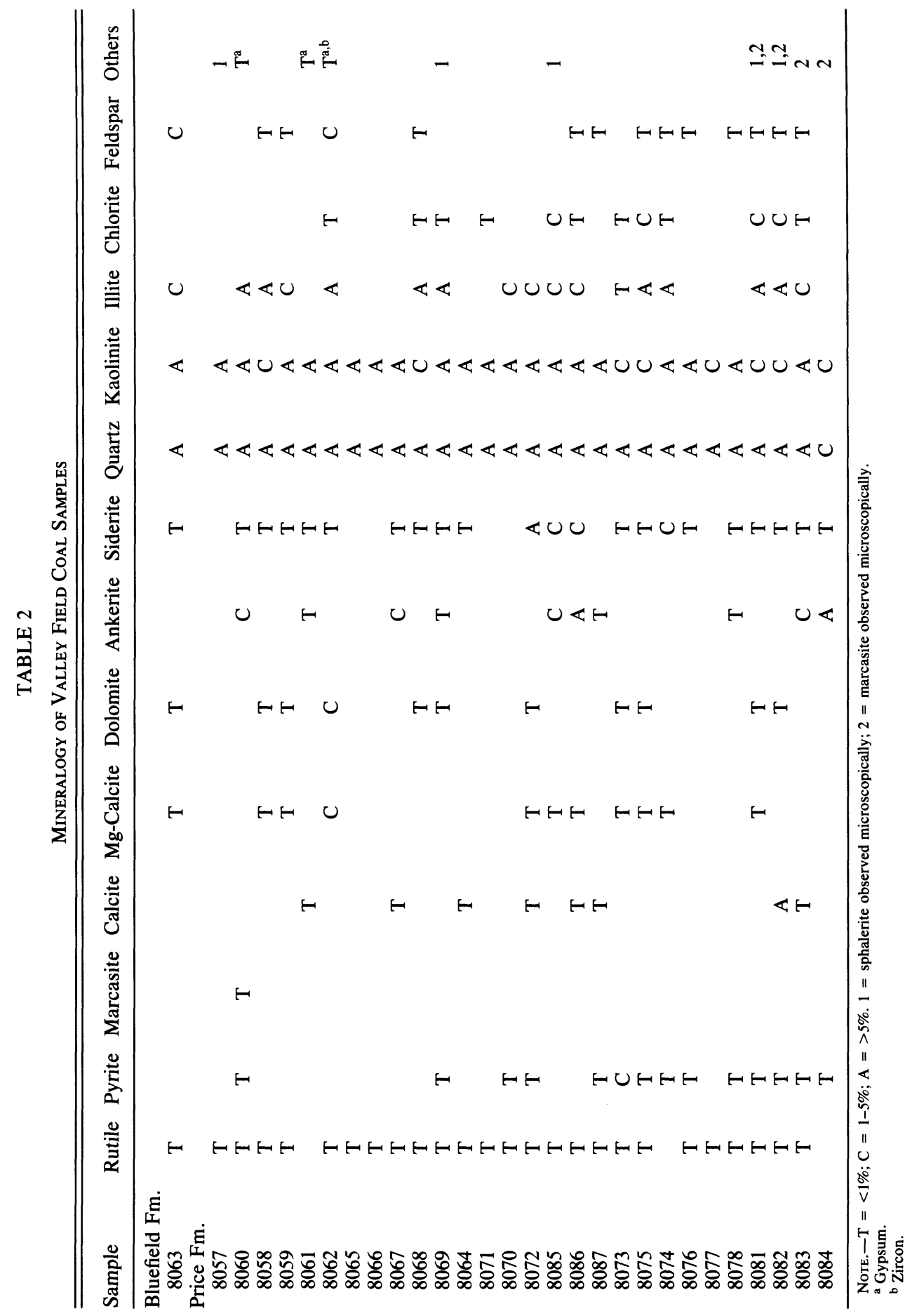




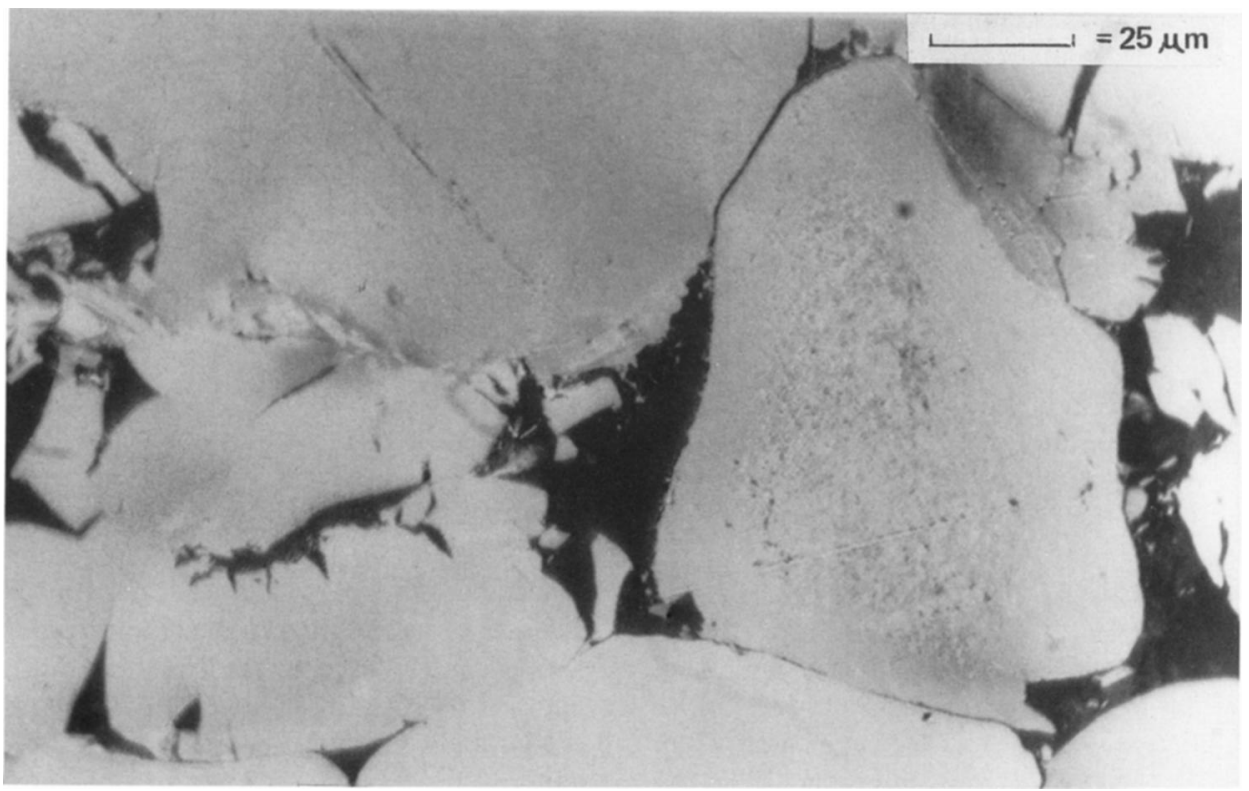

FIG. 5.-Photomicrograph of carbonate cement in corpocollinite breccia.

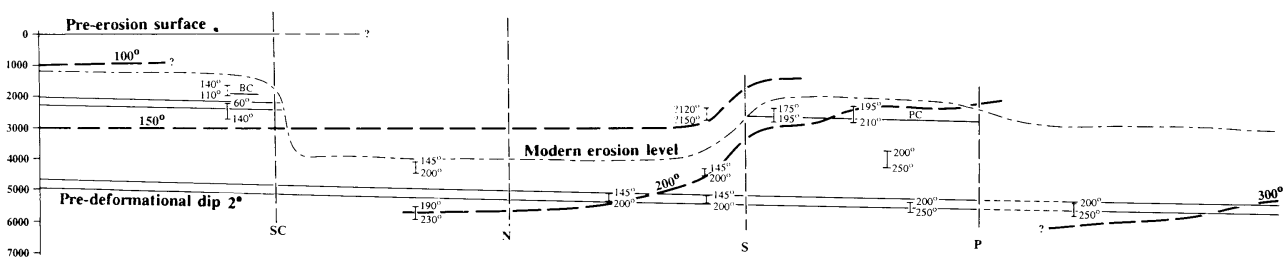

FIG. 6.-Diagram depicting predeformational strata along line of cross section shown in figure 2, with inferred isothermal lines based on temperature ranges from CAI values and vitrinite reflectance values. CAI values along line of cross section supplied by A. G. Harris. PC-Price Mountain coals; BC-Bluefield coal; SC-St. Clair thrust; N-Narrows thrust; $\mathrm{S}-$ Saltville thrust; P-Pulaski thrust. Dashed temperature-range bars projected into line of section. Approximate $2^{\circ}$ regional dip on Middle Ordovician limestone (solid lines) from regional decollement dip of Harris et al. (1981).

$200^{\circ} \mathrm{C}$ for heating of the Price Formation coals.

Using cathodoluminescence, Grover and Read (1983) described a complex cementation history with different generations of cements in Middle Ordovician ramp carbonates from across the Valley and Ridge Province in Virginia. Earlier-formed, dull calcite and ferroan dolomite cements reflect burial diagenesis conditions of subtidal carbonate beds during the Late Devonian to early Mississippian in the foreland basin and are associated with hydrocarbons and temperatures from $75^{\circ} \mathrm{C}$ to $135^{\circ} \mathrm{C}$. They concluded that the youngest, clear, dull cements that fill tectonically generated fractures probably formed in association with Alleghanian tectonism, probably at higher temperatures and greater depths $\left(200^{\circ} \mathrm{C}\right.$ to $300^{\circ} \mathrm{C}$ and 5 to $7 \mathrm{~km}$, from Epstein et al. 1977). They found burial cements to be best-developed in the southeastern versus the northwestern portion of the Valley and Ridge Province. Dorobek (1987, p. 510) discusses the hinterlandward increase in the proportion of late dolomite cement, plus formation of fluorite, in Siluro-Devonian Helderberg Group carbonate rocks of the central Appalachians. He concluded that the formation of late dolomite cement plus fluorite took place ". . . just prior to and during late Paleozoic 
deformation" at temperatures in the $200^{\circ} \mathrm{C}$ range. Elliot and Aronson (1987) found that the extent of illitization of mixed-layer illite/ smectite in Ordovician-age $K$ (potassium)bentonites near, and west of, the structural front was similar, regardless of inferred depth of burial of the K-bentonites. They attributed the illitization to exposure to hot brines expelled during Alleghanian tectonism farther southeast.

Burial.-Regional reconstruction of preerosion stratigraphy would restore at least 4 km of Cambrian through Mississippian (lower Price Formation) strata, a section similar to that preserved in the western Salem synclinorium portion of the Pulaski thrust sheet (Bartholomew 1987), structurally above the Price Mountain window (figs. 3 and 4). Replacing an additional 2-3 km of late Paleozoic strata (removed by erosion) would suggest ca. $7 \mathrm{~km}$ of rock atop the Price Mountain coals on the Saltville thrust sheet. The $7 \mathrm{~km}$ of strata would include: $2-3 \mathrm{~km}$ of eroded late Paleozoic strata; the preserved $(4 \mathrm{~km})$ Cambrian through (lower) Mississippian column above the Pulaski thrust; plus the thickness of the upper Price and Maccrady formations (0.5 km) below the Pulaski thrust (figs. 3 and 4). Indicated burial depths (this study; Epstein et al. 1977; Zentmeyer 1985) are consistent with the total known stratigraphic thickness above Mississippian coal-bearing strata (on their respective thrust plates) plus known stratigraphic thickness from structurally superjacent thrust sheets. Thus Middle Ordovician limestones on the Saltville sheet were beneath ca. 9-10 km of strata.

The Mississippian Greenbrier Formation is only $0.4 \mathrm{~km}$ below the coal in the Bluefield Formation (fig. 4), but these rocks were likely buried to a greater depth beneath the structurally higher St. Clair thrust sheet originally containing about $3.5-4 \mathrm{~km}$ of Cambrian-Mississippian strata above the overturned limb of the Glen Lyn syncline in the Glen Lyn area (fig. 3).

Comparison with Other Areas.-The divergence between maximum and mean vitrinite reflectances (anistropy) is considered a signature of the tectonic history of coal metamorphism (Hower and Davis 1981; Levine and Davis 1989a, 1989b). Reflectance anisotropy of the Mississippian-age Valley Field semi-anthracites studied here is significantly less than that of semi-anthracites from the Bernice Field (one of the North-Central fields) in Sullivan County, Pennsylvania (Hower 1978). The Bernice semi-anthracites occupy an apparent stable tectonic setting on the Allegheny Plateau and represent the highest rank found among coals involved only in plateau tectonics. Hower (1978) and Hower and Paxton (1979) interpreted the depth of burial for the Bernice Field to be about 3.5-4 $\mathrm{km}$, similar to burial of nearby fields of lower rank, and the rank to be a consequence of a higher paleogeothermal gradient than in fields to the northwest. Upon further consideration of sandstone porosity, Paxton (1983) proposed that the depth of burial of Pennsylvanian coals increased progressively from the North-Central fields to the Northern Anthracite Field with little change in paleogeothermal gradient through the region. The Bernice semi-anthracites would have been metamorphosed at a depth of about 5.7-6 km according to his revised model. Our range of 4.5-7 $\mathrm{km}$ of restored depositional strata plus structural overburden above the Mississippian coals of the Saltville thrust sheet approximates the depth of burial for Bernice Field coals determined by Hower (1978) and Hower and Paxton (1979). [The difference in anisotropy for the Valley Field coals compared to those of the Bernice Field could be due to either greater burial depth (as suggested by Paxton 1983) for Bernice Field coals or to shorter burial/heating time for Valley Field coals.]

\section{DISCUSSION}

Available data suggest that the Valley and Ridge Province, as well as adjacent areas, experienced maximum thermal effects during the Alleghanian orogeny (cf. Epstein et al. 1977; Grover and Read 1983). Vitrinite reflectance data of Mississippian coal, CAI values (of Ordovician-Mississippian limestones), and cathodoluminescence patterns of carbonate cements (in Ordovician and Siluro-Devonian strata) are all consistent with a heating maxima increasing hinterlandward across the Valley and Ridge Province. However, the signature of this thermal event varies as a function of intensity, character, and timing across the Valley and Ridge in Virginia. Relationships among the thermal event, mineral precipitation in carbonates 
and coal, and regional structural features serve to delineate some components of the relative emplacement sequence of the thrust sheets.

Thermal Event Relative to Thrust Sheet Emplacement.-The Pulaski thrust sheet consistently shows higher-rank CAI values (4-5: Epstein et al. 1977; Harris 1979; Orndorff et al. 1988) than those thrust sheets to the west. Disruption of CAI values (Epstein et al. 1977; Harris 1979) indicates that the Pulaski sheet was emplaced after its peak thermal event as Harris (1979, p. 9) noted: “. . . in the southeastern part of the basin, isograds are disrupted and irregular, because late Paleozoic thrusting has severed and telescoped original metamorphic isograd patterns." Our data suggest its emplacement was just prior to, or during, the event affecting the Saltville thrust sheet. Because of the large transport distance (ca. $100 \mathrm{~km}$, Bartholomew 1987), the thermal event affecting the Pulaski thrust sheet could be, but is not required to be, different from those that affected the forelandward part of the Valley and Ridge Province.

On the Saltville thrust sheet, geothermometry indicators (CAI and vitrinite reflectance) imply relatively high temperatures well up into the Mississippian section (fig. 6). Although rocks of the Saltville thrust sheet were subjected to a thermal maximum after emplacement of the Pulaski thrust sheet, the rather steep thermal gradient from the Saltville thrust sheet to the structurally lower Narrows thrust sheet, suggests significant offset of isotherms by the Saltville thrust (fig. 6). The existence of this thermal break is also implied by the data of Campbell and Others (1925), who found significantly lower rank coals on the Narrows as compared to the Saltville thrust sheet. The Saltville thrust sheet was thus emplaced during or slightly after its own thermal peak.

Both the Narrows and St. Clair thrust sheets show lower CAI values (3.5) in Middle Ordovician-Devonian strata than either the superjacent Saltville or Pulaski thrust sheets (Epstein et al. 1977). CAI values are somewhat higher (4-4.5) from the Lower Cambrian Knox Group both within the Narrows sheet and from structurally slightly below the Narrows thrust sheet in the Bane dome. The latter values are indicative of temperatures of $190^{\circ}$ to $230^{\circ} \mathrm{C}$ (Perry et al. 1979), whereas the former values are indicative of $150^{\circ}$ to $175^{\circ} \mathrm{C}$ (Epstein et al. 1977). Locally, near Glen Lyn, Virginia, anomalously high CAI values $(3.5$ in Mississippian Greenbrier Formation and 4 in Upper Ordovician Martinsburg Formation) are from an area where the St. Clair thrust sheet is structurally very thin.

Thermocline and Its Cause.-The hinterlandward-increasing thermocline could result from:(1) stratigraphic thickening to the southeast; (2) progressive hinterlandward structural burial by stacking of multiple thrust sheets as proposed by Levine (1986) for the Pennsylvania anthracites and also discussed by Epstein et al. (1977); and/or (3) an undiscerned (fluid-laden) heat source to the southeast, similar to the proposed heat source for Pennsylvania anthracites (Daniels et al. 1990; Daniels and Altaner 1990).

Stratigraphic burial certainly influenced geothermometry signatures within the Valley and Ridge thrust sheets. Total preserved stratigraphic thicknesses above the Middle Ordovician limestones from successive thrust sheets show a hinterlandward decrease (figs. 3 and 4) from about $4.5 \mathrm{~km}$ near the Glen Lyn above the Middle Ordovician limestones near Glen Lyn to about $3 \mathrm{~km}$ near Price Mountain. But more likely estimates of total thickness determined using a predeformational dip of ca. $2^{\circ}$ (Bartholomew 1987; Harris et al. 1981) are ca. $5.5-6 \mathrm{~km}$ of strata above the Middle Ordovician limestone near Price Mountain compared with ca. $5 \mathrm{~km}$ at Glen Lyn (fig. 6). Regardless, reconstructed thicknesses are similar enough that if stratigraphic burial were the sole or dominant control, geothermometry values should be relatively uniform across the area.

In some instances, structural burial influenced geothermometry signatures. Along the structural front of the fold and thrust belt (150 km west of our area), O'Hara et al. (1990) found lower $R_{\max }$ values above the Pine Mountain thrust, as opposed to slightly higher $\mathbf{R}_{\max }$ values below the thrust sheet in samples from equivalent coal units, indicating emplacement of the Pine Mountain thrust sheet prior to the thermal peak. At Glen Lyn a similar relationship is inferred along the structural front, although the front differs structurally from the Pine Mountain thrust. Here, the weathered, and hence minimum 
(see Ingram and Rimstidt 1984), $1.35 \% \mathrm{R}_{\max }$ value $\left(1.21 \% R_{\text {mean }}\right)$ for Bluefield coal is somewhat low compared with a nearby anomalously high CAI index of 3.0 (Epstein et al. 1977) from the Mississippian Greenbrier Formation ( $400 \mathrm{~m}$ below the Bluefield). Both are high for simple stratigraphic burial beneath $<2 \mathrm{~km}$ of Mississippian and Pennsylvanian strata. They are, however, compatible with the added burial depth beneath the structurally higher St. Clair thrust sheet containing about 3.5-4 km of Cambrian-Mississippian strata above the overturned limb of the Glen Lyn syncline in this area.

Thermal Event and Coal Metamorphism.- In addition to the overburden added by the Pulsaki sheet to coals of the Saltville sheet, the Pulaski thrust may have exerted some control on the movment of hydrothermal fluids. Daniels and Altaner (1990) and Daniels et al. (1990) considered similar mechanisms in the Pennsylvania anthracite fields. Progressive foreland-directed movements of thrust sheets, combined with fluid expulsions associated with orogenic uplift to the east, may be mechanisms contributing to the movement of thermal fluids. Such hydrothermal waters may originate in overpressured zones and can contain high concentrations of metals such as lead and zinc (Jones 1977). Cathles and Smith (1983) and Oliver (1986) attributed Mississippian Valley-type ore deposits such as in the Illinois-Kentucky Fluorspar District, to periodic expulsion of brines from geopressured zones. Among our unweathered samples, carbonate fracture-filling mineralization is present only in coals with $R_{\max }>1.95 \%$, suggesting that mineralizing fluids may have played a role in the metamorphism. Intense fracturing of some coals, noted in this study as well as by Campbell and Others (1925) and Stanley and Schultz (1983), may have provided conduits for the fluids.

Campbell and others (1925) noted significant rank differences between the Langhorne (12.0-12.9\% volatile matter, daf) (see reflectance analysis for KCER 8060) and the Merrimac (21.6\% volatile matter, daf) coal beds in the Empire Mine (where they are only about $4 \mathrm{~m}$ apart), Little Walker Mountain Field, Pulaski County. Campbell and Others (1925), a proponent of thrust pressure as a prime contributor to organic metamorphism, attributed the differences in rank to differences in resistance to thrusting between the fractured Merrimac and the hard, resistant Langhorne. Bustin (1983), in a study of coals involved in thrusting in the Cordilleran fold and thrust belt in Montana, Alberta, and British Columbia, found no evidence for any significant fault influence on metamorphism. However, O'Hara et al. (1990) did document some evidence for localized shear-influenced heating in coals on the Pine Mountain thrust sheet in southeastern Kentucky. $R_{\max }$ values (this study) from a different locality but from the same seams Campbell and Others (1925) examined in the Empire mine (samples 8061-8062, Route 100; table 1) show an inverse relationship in rank where the fractured Langhorne is the locus of a small footwall thrust associated with the Pulaski fault and has significantly higher rank than the relatively undeformed Merrimac seam. Inasmuch as most of the fractured samples show evidence of fluid-borne post-fracture mineralization, we believe the observed rank differences are more likely due to differences in accessibility to fluid flow at the time of metamorphism. Considering the effects of thermal perturbations induced by hydrothermal fluids, conventional arguments for estimation of depth of metamorphism using rank gradients and inferred temperature gradients must be used with deliberate caution in areas of fluidborne post-fracture mineralization.

Late-stage fracture-filling carbonate cements, plus fluorite or sulphides, in nearby Valley and Ridge carbonates (Grover and Read 1983; Dorobek 1987), along with the epigenetic minerals associated with breccias and fracturing of Valley Field coals, appear to be part of an extensive (maximum temperature ca. $200^{\circ} \mathrm{C}$ ) fluid movement event (such as depicted by Morton 1985; Garven and Freeze 1984; Oliver 1986) during Alleghanian deformation. These fluids likely had a major effect on coal metamorphism and diagenesis as a whole, especially in the southeasternmost Valley and Ridge Province. Temporal/ spatial association between probable Alleghanian fracturing and mineral-laden fluids might be comparable with models similar to earthquake-generated, locally dilational, mineralized zones (Sibson 1987), although orientation of the stress field here would be entirely different from that associated with 
transform fault zones such as the San Andreas. Here, the creation of localized subhorizontal dilational zones with preferred fluid movement essentially parallel to bedding planes would have been favored. Both Clendenin and Duane (1990) and Leach and Rowan (1986) discuss the role of tectonically derived fluids in the formation of Mississippi Valley-type ore deposits. Clendenin and Duane (1990) ascribe a major role to "seismic pumping" of hot fluids during faulting. Similar mechanisms would foster pervasive redistribution [and perhaps "boiling" conditions, such as described by Sibson (1987)], of interstitial fluids.

Age of Thermal Event.-K-Ar ages of illitization determined by Elliot and Aronson (1987) suggest a minimum 30 m.y. duration (303-273 Ma) for heating time. The $303 \mathrm{Ma}$ K-Ar date, which Elliot and Aronson (1987) indicate is their oldest mean age of illitization, comes from significantly west of the Pulaski sheet; hence, movement on the Pulaski thrust may have begun prior to the $300 \mathrm{Ma}$ oldest age of illitization. Thus the age span for the western Valley and Ridge thermal event is compatible with Alleghanian as defined by the Valley and Ridge thrusting event. Moreover, it largely overlaps other radiometrically constrained Alleghanian deformation in the Appalachians such as in the Kiokee belt (315-295 Ma) and in the South Carolina slate belt as determined by ${ }^{40} \mathrm{Ar} /{ }^{39} \mathrm{Ar}$ data (Dallmeyer et al. 1986). Also, Sinha et al. (1989) place the Permo-Carboniferous (Alleghanian) igneous activity of the Piedmont at 330-270 Ma.

Thrusting and Metamorphism of Virginia Valley and Ridge.-If the total duration of the heating event was pre- to syn-thrusting, the Blue Ridge thrust sheet could not have extended as far as the Price Mountain window, which is $10-12 \mathrm{~km}$ forelandward of its present-day trace (see above-surface projection, fig. 3), for any significant period of time; or if it did, it did not affect geothermometry signatures, because added overburden should have resulted in both higher vitrinite reflectance values (Mississippian) and higher CAI values (Ordovician), as well as a difference in other temperature indicators. Thus, at the time of peak "metamorphism," rocks of the Price Mountain window lay (as shown in fig. 3) beneath the Pulaski thrust sheet, but not beneath both it and the Blue Ridge thrust sheet. Structural limitations are also imposed on the Glen Lyn syncline, for if the Narrows thrust sheet had extended this far forelandward overtop the St. Clair thrust sheet for any significant length of time, the structurally doubled thickness would have resulted in significantly higher $\mathbf{R}_{\max }$ values.

The distribution of low volatile bituminous $R_{\max }$ values (fig. 2; sample numbers 8065 and 8070-8072) suggests that vitrinite reflectance may decrease slightly just northwest of the present day Pulaski thrust trace. This small difference, if significant, could have resulted from (1) especially rapid erosion of the overlying Pulaski sheet from that region, perhaps because of significant tilting of the southeast limb of the Sinking Creek anticline during Saltville thrust propagation (fig. 3); (2) structural thinning of the Pulaski sheet because the Pulaski fault ramped from the Cambrian Rome Formation upward to a stratigraphically higher glide horizon (fig. 3); and/or (3) differential access for warm fluids escaping from tectonic highlands to the east. Mechanisms (1) or (2) may have been operative with limitations (cf. Edman and Furlong 1987; Warner and Royse 1987). They discussed thermal effects from emplacement of superjacent thrust sheets but did not consider the role of introduced fluids, which may not have been pertinent to their examples. We favor differential fluid access to be at least as important, if not the dominant, reason for the observed variations because, in our samples, fractures allowing fluid access produce contrasting effects over several meters. This interpretation is compatible with Grover and Read (1983) and Dorobek (1987).

The forelandward sequencing of thrusts (Pulaski followed by Saltville and more westerly thrusts) supports Perry's (1978) interpretation that Appalachian thrust development was from the hinterland toward the foreland. CAI isograds north of the Roanoke recess are not offset (Harris 1979); hence (1) two separate thermal events affected the central and southern Appalachians, or (2) the heating event in the central Appalachians north of the recess continued throughout thrusting, or (3) the thrust movement there occurred before the thrusting west of the Pulaski-Staunton thrust system in the southern Appalachians where CAI isogrades are offset (Harris 1979). 
The last alternative is in contradistinction to the conclusion of Bick (1986) that forelandward of the Pulaski-Staunton fault, northern Appalachian thrusting post-dates southern Appalachian thrusting. Bick's interpretation is possible if (1) either two separate thermal events occurred, or if (2) the thermal event affected the central Appalachians for a significantly longer period of time.

\section{CONCLUSIONS}

1) $R_{\max }$ values from Mississippian-age Price Formation coals range from $2.07 \%$ to $2.60 \%$ in the Price Mountain window, and from $1.61 \%$ to $2.56 \%$ in Saltville thrust sheet rocks beneath the present day leading edge of the Pulaski thrust. These $\mathbf{R}_{\max }$ values are compatible with CAI values and other geothermometry indicators (Epstein et al. 1977; Ingram and Rimstidt 1984; Zentmeyer 1985), which suggest temperatures of Alleghanian "metamorphism" of $200 \pm 25^{\circ} \mathrm{C}$ on the Saltville thrust sheet. Depth-of-burial for the coals was at least $4.5 \mathrm{~km}$, and more likely $6-7 \mathrm{~km}$, as reconstructed from both stratigraphic and structural data. The Pulaski thrust sheet was emplaced before the thermal maximum was attained in the Saltville thrust sheet.

2) Temperatures of ca. $200^{\circ} \mathrm{C}$ were maintained higher in the stratigraphic section (Mississippian strata) on the Saltville thrust sheet than on the both the subjacent Narrows and St. Clair thrust sheets. The steep temperature gradient across the Saltville thrust suggests both significant displacement on the Saltville thrust and that the respective thermal maxima were attained on both the $\mathrm{Pu}$ laski and Saltville thrust sheets prior to, or during, their emplacement above the more westerly Valley and Ridge thrust sheets. Thermal maxima on the Narrows and St. Clair thrust sheets were probably reached post-emplacement.

3) Local variation in $R_{\max }$ values within the Saltville thrust sheet and decrease of $R_{\max }$ from southeast to northwest may, locally at least, be influenced as much by the temperature of, and access to, fluids expelled during Alleghanian tectonism as by either stratigraphic or tectonic burial.

ACKNOWLedgments. - The balanced cross section in figure 4 is generalized from the geologic map of the Radford 1:100,000 quadrangle (in preparation for the U.S. Geol. Survey misc. map series) by M. J. Bartholomew, A. P. Schultz, S. E. Lewis, and R. C. McDowell. A. P. Schultz, S. P. Altaner, E. J. Daniels, W. J. Perry, Jr., M. J. Bartholomew, and one anonymous reviewer helped significantly to improve the manuscript. A. G. Harris generously supplied sample locations for CAI data in the region.

\section{REFERENCES CITED}

BARTholomew, M. J., 1987, Structural evolution of the Pulaski thrust system: Geol. Soc. America, Bull., v. 99, p. 491-510.

, and Lowry, W. D., 1979, Geology of the Blacksburg quadrangle, Virginia: Virginia Div. Min. Res. Pub. 14, text and 1:24,000 map.

Bick, K. F., 1986, Structure of the Sugarloaf Mountain area: intersecting trends on the northeast flank of the Roanoke reentrant, Virginia, in MCDowell, R. C., and Glover, L., III, eds., The Lowry volume: studies in Appalachian geology: Virginia Tech Geol. Sciences Mem. 3, p. 27-36.

Brown, K. E., 1983, Stratigraphy and deformation of the Price Formation coals in Montgomery and Pulaski counties, Virginia: Unpub. M.S. thesis, Virginia Polytech. Inst. and State Univ., Blackburg, Virginia, $77 \mathrm{p}$.

Bustin, R. M., 1983, Heating during thrust faulting in Rocky Mountains: friction of fiction?: Tectonophysics, v. 95, p. 309-328.

Campbell, M. R., ET al., 1925, The Valley Coal Fields of Virginia: Virginia Geol. Survey Bull. $25,32 \mathrm{p}$.

Caphles, L. M., and Smith, A. T., 1983, Thermal constraints on the formation of Mississippi Valley-type lead-zinc deposits and their implications for episodic basin dewatering and deposit genesis: Econ. Geol., v. 78, p. 983-1002.

Clendenin, C. W., and Duane, M. J., 1990, Focused fluid flow and Ozark Mississippi Valleytype deposits: Geology, v. 18, p. 116-119.

Cooper, B. N., 1961, Grand Appalachian excursion: Virginia Polytech. Inst. and State Univ. Dept. Geol. Sci. Guidebook 1, 187 p.

Dallmeyer, R. D.; Wright, J. E.; Secor, D. T., JR.; and SNOKe, A. W., 1986, Character of the Alleghanian orogeny in the southern Appalachians: part II. Geochronological constraints on the tectonothermal evolution of the eastern Piedmont in South Carolina: Geo. Soc. America Bull., v. 97, p. 1329-1334.

Daniels, E. J., and Altaner, S. P., 1990, Clay mineral authigenesis in coal and shale from the Anthracite region, Pennsylvania: Amer. Mineral., in press.

- ; MarshaK, S.; and Eggleston, J. R., 1990, Hydrothermal alteration in anthracite from eastern Pennsylvania: implications for 
mechanisms of anthracite formation: Geology, in press.

DAvis, A., 1978, The reflectance of coal, in KARR, C., ed., Analytical Methods for Coal and Coal Products-I: New York, Academic Press, p. 27-81.

Dorobek, S. L., 1987, Petrography, geochemistry, and origin of burial diagenetic facies, Siluro-Devonian Helderberg Group (carbonate rocks), central Appalachians: Am. Assoc. Petrol. Geol. Bull., v. 71, p. 492-514.

Edman, J. D., and Furlong, K. P., 1987, Thrust faulting and hydrocarbon generation: reply: Am. Assoc. Petrol. Geol. Bull., v. 71, p. 890-986.

Elliot, W. C., and Aronson, J. L., 1987, Alleghanian episode of $\mathrm{K}$-bentonite illitization in the southern Appalachian basin: Geology, v. 15. p, 735-739.

Epstein, A. G.; Epstein, J. B., and Harris , L. D., 1977, Conodont color alteration: an index to organic metamorphism: U.S. Geol. Survey Prof. Paper 995, 27 p.

Garven, G., and Freeze, R. A., 1984, Theoretical analysis of the role of groundwater in the genesis of stratabound ore deposits, 1. Mathematical and numerical model: Am. Jour. Sci., v. 284, p. 1085-1124.

Grover, G., JR., and Read, J. F., 1983, Paleoaquifer and deep burial related cements defined by regional cathodoluminescent patterns, Middle Ordovician carbonates, Virginia: Am. Assoc. Petrol. Geol. Bull., v. 67, p. 1275-1303.

Harris, A. G., 1979, Conodont color alteration, an organo-mineral metamorphic index, and its application to Appalachian Basin geology, in Scholle, P. A., and Schluger, P. R., eds., Aspects of diagenesis: SEPM Spec. Pub. 26, p. 3-16.

Harris, L. D.; Harris, A. G.; DeWitt, W., JR.; and BAYER K. C., 1981, Evaluation of southern eastern overthrust belt beneath Blue Ridge-Piedmont thrust: Am. Assoc. Petrol. Geol. Bull., v. 65, p. 2497-2505.

Hower, J. C., 1978, Anisotropy of vitrinite reflectance in relation to coal metamorphism for selected United States coals: Unpub. Ph.D. dissertation, The Pennsylvania State Univ., Univ. Park, 339 p.

$\longrightarrow$, and DAvis, A. 1981a, Vitrinite reflectance anisotropy as a tectonic fabric element: Geology, v. 9, p. 165-168.

, and $-1981 a$, Application of vitrinite reflectance anisotropy in evaluation of coal metamorphism: Geol. Soc. America Bull., v. 92, p. 350-366.

, and Paxton, S. T., 1979, Concomitant coal metamorphism-sandstone textural modifications in the Pennsylvanian of the North-central fields, Pennsylvania: 9th Int. Cong. Carbon. Stratig. Geol., Abs. of Papers, p. 93.

- , and RIMmer, S. M., 1990, Coal rank trends in the Central Appalachian coalfield: Virginia, West Virginia, and Kentucky: Organic Geochem., v. 15 , in press.

IngRAM, G., and RimstidT, D., 1984, Natural weathering of coal: Fuel, v. 63, p. 292-296.
Jones, P. H., 1977, Geopressured geothermal energy in the south-central United States, in CAMPBELL, M. D., ed., Geology of Alternate Energy Resources in the South-Central United States: Houston, Texas, Houston Geol. Society, p. 215-250.

Juster, T. C.; Brown, P. E.; and Bailey, S. W., $1987, \mathrm{NH}_{4}$-bearing illite in very low-grade metamorphic rocks associated with coals, northeastern Pennsylvania: Am. Mineral., v. 72, p. 555-565.

Kreisa, R. D., and BAmbaCH, R. K., 1973, Environments of deposition of the Price Formation (Lower Mississippian) in its type area, southwestern Virginia: Am. Jour. Sci., v. 273-A, p. 326-342.

Leach, D. L., and Rowan, E. L., 1986, Genetic link between Ouachita foldbelt tectonism and the Mississippi Valley-type lead-zinc deposits of the Ozarks: Geology, v. 14, p. 931-935.

LEVINE, J. R., 1986, Deep burial of coal-bearing strata, Anthracite region, Pennsylvania: sedimentation or tectonics?: Geology, v. 14, p. $577-580$.

- , and DAvis, A., 1981a, The relationship of coal optical fabrics to Alleghanian tectonic deformation in the central Appalachian fold-andthrust belt, Pennsylvania: Geol. Soc. America Bull., v. 101, p. 1333-1347.

$\longrightarrow$, and $\longrightarrow, 1989 \mathrm{~b}$, Reflectance anisotropy of Upper Carboniferous coals in the Appalachian foreland basin, Pennsylvania, USA: Inter. Jour. Coal Geol., v. 13, p. 341-373.

Lewis, S. E., and Bartholomew, M. J., 1989, Orphans-exotic, detached duplexes within thrust sheets of complex history: Geol. Soc. America Abs. with Prog., v. 21, p. A136.

Morton, J. P., 1985, Rb-Sr dating of clay diagenesis and source age of clays in Upper Devonian black shales of Texas: Geol. Soc. America Bull., v. 96, p. 1043-1049.

O'Hara, K.; Hower, J. C.; and Rimmer, S. M., 1990, Constraints on the emplacement and uplift history of the Pine Mountain thrust sheet, eastern Kentucky: evidence from coal rank trends: Jour. Geology, v. 98, p. 43-51.

Oliver, J., 1986, Fluids expelled tectonically from orogenic belts: their role in hydrocarbon migration and other geologic phenomena: Geology, v. 14, p. 99-102.

OrndorfF, R. C.; Harris, A. G.; and Schultz, A. P., 1988, Revaluation of conodont color alteration patterns in Ordovician rocks, east-central Valley and Ridge and western Blue Ridge provinces, Tennessee: U.S. Geol. Survey Bull. 1839, Chap., D, 10 p.

Paxton, S. T., 1983, Relationships between Pennsylvanian-age lithic sandstone and mudrock diagenesis and coal rank in the central Appalachians: Unpub. Ph.D. dissertation, The Pennsylvania State Univ., Univ. Park, 503 p.

PERRY, W. J., JR., 1978, Sequential deformation in the central Appalachians: Am. Jour. Sci., v. 278, p. 518-542.

RAST, N., 1989, The evolution of the Appalachian chain, in BAlly, A. W., and PAlmer, A. R., eds., 
The Geology of North America-An Overview, Vol. A: Boulder, Colorado, Geol. Soc. America, p. 323-348.

Schultz, A. P., 1988, Horses in Fensters of the Pulaski thrust sheet, southwestern Virginia: structure, kinematics, and implications of hydrocarbon potential of the eastern overthrust belt: U.S. Geol. Survey Bull. 1839A, 13 p.

; Stanley, C. B.; Garthright, T. M.; Rader, E. K.; Bartholomew, M. J.; Lewis, S. E.; and Evans, N. H., 1986, Geologic map of Giles County, Virginia: Virginia Div. Min. Res. Pub. 69 , scale $1: 50,000$.

Sibson, R. H., 1987, Earthquake rupturing as a mineralizing agent in hydrothermal systems: Geology, v. 15, p. 701-704.

Sinha, A. K.; Hund, E. A.; and Hogan, J. P., 1989, Paleozoic accretionary history of the North American plate margin (central and southern Appalachians): constraints from the age, origin, and distribution of granitic rocks, in Hillhouse, J. W., ed., Deep structure and past kinematics of accreted terranes: Am. Geophys. Union, Mon. 50, p. 219-238.

Stanley, C. B., and Schultz, A. P., 1983, Coal bed methane resource evaluation, Montgomery County, Virginia: Virginia Div. Min. Res. Pub. 46, $59 \mathrm{p}$.

WARNER, M. A., and Royse, F., 1987, Thrust faulting and hydrocarbon generation: discussion: Am. Assoc. Petrol. Geol. Bull., v. 71, p. 882-889.

WhiTEHEAD, N. H., III, 1979, Lithostratigraphy of the Grainger-Price Formation, northeastern Tennessee and southwestern Virginia, depositional history of the Lower Mississippian of the eastcentral United States: Unpub. Ph.D. dissertation, Univ. of North Carolina, Chapel Hill, $214 \mathrm{p}$.

Zentmeyer, J. P., 1985, Petrology and diagenesis of the Lower Mississippian Price Formation, southwestern Virginia: Unpub. M.S. thesis, Virginia Polytech. Inst. and State Univ., Blacksburg, $154 \mathrm{p}$. 